\title{
CITRA PEREMPUAN DALAM NASKAH \\ SYAIR NABI ALLAH AYUB (ANONYMOUS) DALAM PRESPEKTIF ISLAM: KAJIAN SEMIOTIK
}

\author{
Iik Idayanti, Nining Sudiar, Yuhelmi \\ Fakultas Ilmu Budaya Universitas Lancang Kuning
}

\begin{abstract}
A manuscript entitled Syair Nabi Allah Ayub becomes the object of this study. It is written in Jawi. The manuscript was fisnished in the Barus, on 24-3-1273 or 22-11-1856. The text contains the life journey of the Prophet Ayub being tested by God with various trials. At the end of story, Angel Jibril and Mikail released all the trials and the Prophet Ayub regained its former glory. Many things can be explored with regard to the content of the texts, one of them about the imagery of woman in Islam described in the text of Syair Nabi Allah Ayub. It is analyzed by using Roland Barthes' semiotic concept.
\end{abstract}

Keywords: Manuscript, Syair Nabi Allah Ayub, Woman Imagery

\section{A. PENDAHULUAN}

Butir-butir mutiara kebudayaan Indonesia pada masa lampau yang sampai kepada kita sebagai warisan kebudayaan para leluhur antara lain terdapat di dalam berbagai cerita rakyat yang masih diturunkan dari mulut ke mulut yang kini telah banyak direkam di dalam berbagai tulisan. Di samping itu, ada warisan budaya yang lain berupa naskah yang bermacammacam bentuk dan ragamnya, yang tersebar di seluruh Indonesia dan ditulis dalam berbagai bahasa daerah dan huruf (Mulyadi, 1994: 1). Diantara ragam bahasa yang ada, bahasa Melayu merupakan salah satu bahasa yang memiliki rekaman tertulis dalam bentuk naskah.

Ikram (1997: 36) menambahkan, peninggalan naskah lama dalam bahasa Melayu termasuk yang paling besar jumlahnya, di samping bahasa Bali dan Jawa. Naskah lama yang jumlahnya banyak tersebut membuktikan betapa penting dan berharganya aset budaya yang kita miliki, dalam hal ini berkaitan dengan isi kandungan naskah yang luas dan beragram, meliputi bidang agama, sejarah, sastra, mitologi, seni, hukum, 
ilmu kemasyarakatan, cerita rakyat, myte, legenda, adat-istiadat dan serbaserbi (Pigeaud dalam Lantiani, 1996: 1). Teks-teks naskah dengan beragam kandungan isi tersebut kebanyakan dituangkan oleh penulis atau penyalin naskah dalam bentuk syair dan hikayat. Hal tersebut merupakan bentuk khas karya tertulis bangsa Melayu pada zaman dulu.

Salah satu naskah lama Melayu yang berbentuk syair berjudul Syair Nabi Allah Ayub (selanjutnya disingkat SNAA). Naskah tersebut merupakan koleksi Bibliotheek Universiteit Leiden. Liaw Yock Fang (2011: 603-604) mengelompokkan teks SNAA ke dalam jenis syair anbia, yaitu syair yang mengisahkan riwayat hidup para nabi (ibid, hlm. 604). Menurut deskripsi naskah yang dikompilasi oleh E.P. Wieringa (2007: 267), teks SNAA berkisah tentang Nabi Ayub, yang hidup di wilayah Kan'an bersama istrinya Rohimah. Nabi Ayub adalah sosok yang kaya raya dan dermawan. Ia diuji oleh Tuhan dengan diberikannya musibah kemiskinan dan penyakit. Berkat kesabaran dan kesalehannya, Tuhan melalui malaikat Jibril dan Mikail membawa berita untuk melepaskan segala penderitaan. Setelah itu Nabi Ayub mendapatkan kembali kejayaannya.

Teks SNAAmenarik untuk diteliti, karena isi teksnya syarat nilai sejarah dan keteladanan tokoh agama. Keteladanan itu dimunculkan pada tokoh-tokoh dalam cerita teks SNAA. Selain tokoh utama, dalam hal ini Nabi Ayub, terdapat satu tokoh yang menjadi bagian dalam cerita teks SNAA, yaitu isteri Nabi Ayub bernama Rohimah. Sosok Rohimah disebut beberapa kali dalam Al-Qur'an. Rohimah diceritakan sebagai isteri yang setia menemani Nabi Ayub dalam kondisi senang maupuan susah. Deskripsi sosok perempuan dalam teks SNAA inilah yang akan diangkat dalam penelitian ini.

Deskripsi merupakan fungsi dari citra atau sebagai metafora (Sorel, George dalam Wellek, Rene dan Austin Warren, 2016: 219). Citra dapat bersifat visual dan mengacu pada pendengaran atau mungkin bersifat psikologis (Wellek, Rene dan Austin Warren, 2016: 219). Apabila yang dideskripsikan adalah sosok perempuan, maka hal yang akan dibahas terkait citra perempuan secara visual, pendengaran, dan psikologis. Citra perempuan memiliki pengertian sebagai semua wujud gambaran mental spiritual dan tingkah laku keseharian perempuan yang menunjukkan "wajah" dan ciri khas perempuan (Sofia dan Sugihastuti, 2003: 190).

Dalam teks SNAA, Rohimah digambarkan sebagai perempuan yang pandai, rajin beribadah, dan kesayangan kerajaan serta rakyatnya. 
Dilain sisi, ia memiliki karakter lembut, tegar dan rapuh, seluruh karakter tersebut jelas tergambar ketika Rohimah mendampingi sang suami yang terkena musibah sakit.

Syair ini tidak hanya menceritakan ketabahan seorang Rohimah dalam menghadapi cobaan penyakit yang diderita suaminya, tetapi juga mengisahkan ujian keimanan seorang perempuan dalam menyikapi musibah. Hal tersebut tampak pada bagaimana perlakuan masyarakat sekitarnya, terlebih fitnah iblis yang tidak pernah berhenti mengganggunya. Ada kalanya Rohimah hampir putus asa menghadapi penderitaan. Tetapi, kehadiran suaminya selalu menyadarkannya untuk tidak berprasangka buruk terhadap ujian yang diberikan Allah.

Persoalan keimanan ini menarik untuk diperbincangkan karena teks ini merupakan teks saduran berasal dari Timur Tengah yang masuk ke tanah Melayu bersamaan dengan persebaran agama Islam. Sehingga, nilai Keislaman dengan sentuhan gaya Melayu pun terasa dalam tiap bait yang ditulis oleh penggubah. Termasuk di dalamnya, bagaimana sentuhan sang penggubah teks menggambarkan sosok perempuan yang setia dan beriman.

Hasbi Indra (2004: 147) menyebutkan bahwa terdapat lima citra perempuan dalam Islam, yaitu citra penyabar, citra memiliki rasa malu, citra sopan dan lembut saat bicara, dan citra memiliki akhlak yang baik. Mengacu pada pendapat Hasbi Indra, penelitian ini akan melihat citra perempuan dalam perspektif Islam yang digambarkan Rohimah dalam teks SNAA.

Berbicara tentang penggambaran sosok Rohimah, dalam teks tentunya terdapat tanda-tanda dan simbolsimbol yang menyiratkan sesuatu, dalam hal ini citra yang merepresentasikan tanda tentang perempuan. Dalam kajian semiotika, tanda dan simbol terbentuk dari segala atribut yang hadir pada untaian-untaian kata-kata dalam syair. Oleh karena itu, alam kata-kata tersebut juga terdapat tanda dan simbol, yang dalam hal ini merepresentasikan tanda tentang perempuan dalam perspektif Islam.

\section{RUMUSAN MASALAH}

Masalah yang diangkat dalam penelitian ini bagaimana citra perempuan dalam teks SNAA dengan menggunakan kajian semiotika?

\section{B. KONSEP}

\section{A. Citra}

Citra (http://kbbi.web.id/citra, akses 8 Januari 2017) adalah gambaran yang dimiliki orang banyak mengenai pribadi, perusahaan, 
organisasi, atau produk. Citra Artinya rupa, gambaran, dapat berupa gambar yang dimiliki orang banyak mengenai pribadi atau kesan mental (bayangan) visual yang ditimbulkan oleh sebuah kata, frasa atau kalimat dan merupakan dasar yang khas dalam sebuah karya prosa dan puisi (Yuliastuti, Skripsi, 2005: 51).

Citra perempuan adalah gambaran yang dimiliki setiap individu tentang perempuan. Baik berupa gambaran mental ataupun gambaran tingkah laku yang direpresentasikan oleh perempuan. Wujud citra perempuan ini dapat digabungkan dengan aspek fisis, psikis, dan sosial budaya dalam kehidupan perempuan yang melatarbelakangi terbentuknya wujud citra perempuan (Sugihastuti, dalam Akbarullah, Supratman dan Yusanto, https://repository. telkomuni vers i t y. a c . i d / p u s tak a / 16.04.1430_jurnal_eproc.pdf).

Perempuan dalam Islam digambarkan sebagai sosok yang berfikir maju, memahami hak dan kewajiban sesuai dengan fitrahnya, memiliki keterampilan tertentu dan sanggup berhadapan dengan pria secara profesional. Perempuan juga bisa menjadi wanita karir, profesional dengan keahlian tertentu (Prabuningrat dalam Nurhasanah, Skripsi, 2016:2).

Merujuk dari penjelasan sebelumnya, Hasbi Indra (2004: 147) menyebutkan bahwa terdapat lima citra perempuan dalam Islam, yaitu citra penyabar, citra memiliki rasa malu, citra sopan dan lembut saat bicara, dan citra memiliki akhlak yang baik.

\section{B. Penelitian Terdahulu}

Teks SNAA sudah dialihaksarakan oleh peneliti pada penelitian sebelumnya dengan judul "Suntingan Teks dan Citra Manusia Saleh dalam Syair Nabi Allah Ayub (Anonymous)" pada tahun 2016. Analisis isi membahas tentang penggambaran sosok Nabi Ayub sebagai manusia saleh dalam teks dan dibandingkan dengan penggambaran konsep kesalehan dalam Al-Qur' an. Peneliti menemukan banyak hal menarik lain yang dapat dikaji dalam teks, salah satunya tentang citra perempuan dalam perspektif Islam. Penelitian ini merupakan lanjutan dari penelitian sebelumnya, penelitian kali ini akan memakai kajian semiotika untuk mengupas citra perempuan dalam teks SNAA dalam prespektif Islam.

Penelitian yang terkait citra perempuan sebenarnya sudah banyak dilakukan. Hal tersebut dapat dijumpai pada penelitian disertasi tahun 2016 berjudul "Citra Perempuan Islam dalam Karya Asma Nadia” oleh Rina Listia. Perbedaan penelitian Rina Listia dan peneliti adalah objek kajiannya. 
Apabila Rina Listia membahas objek karya Asma Nadia, sedangkan objek penelitian penelitian adalah teks naskah Syair Nabi Allah Ayub.

Penelitian lainnya terkait citra perempuan, seperti penelitian skripsi tahun 2014 berjudul "Citra Perempuan dalam Film Kehormatan di Balik Kerudung (Analisis Semiotik)" oleh Multazam. Dalam penelitin Multazam objek kajiannya berwujud film dan berbeda dengan objek peneliti berupa naskah lama.

Penelitian serupa yang memakai objek naskah kuno tidaklah banyak, salah satunya yang pernah dilakukan berjudul "Citra Perempuan dalam Naskah Ratu Dewi Maleka: Kajian Feminisme Ideologis" yang ditulis oleh Ai Rohmawati dan diterbitkan pada Jurnal Jumantara pada tahun 2013. Penelitian tersebut menggunakan teks kisah Ratu Dewi Maleka berbahasa Sunda, berbeda dengan teks SNAA yang objek naskahnya menggunakan teks berbahasa Melayu. Melihat pemaparan diatas, sehingga dapat disimpulkan, penelitian terkait objek naskah kuno, khususnya teks SNAA masih jarang sekali dilakukan.

\section{METODE PENELITIAN}

\section{A. Metode Penelitian}

Penelitian ini menggunakan metode analisis kualitatif dengan menggunakan pendekatan semiotika
Roland Barthes. Pendekatan semiotika digunakan sebagai alat untuk menemukan makna-makna yang tersirat yang ingin disampaikan oleh penulis teks dalam naskah.

Semiotika (http://kbbi.web.id/ semiotika, akses 8 Januari 2017) adalah ilmu (teori) tentang lambang dan tanda (dalam bahasa, lalu lintas, kode morse, dan sebagainya). Analisis semiotic Roland Barthes mengembangkan dua tingkatan penanda yang disebut dengan tingkat denotasi dan konotasi (Pawito, 2007: 163). Denotasi merupakan sistem penanda tingkat pertama (first-order signification) yang terdiri dari hubunan antara penanda (signifier) dan tetanda (signified) dengan realitas eksternal yang ada disekitarnya. Sedangkan konotasi adalah sistem penanda tingkat dua (second-order signification) dimana penanda dan petanda pada tingkat denotasi menjadi penanda untuk petanda yang ada pada wilayah-wilayah budaya. Hal ini dapat digambarkan sebagai berikut (Sobur, 2006: 68-69):

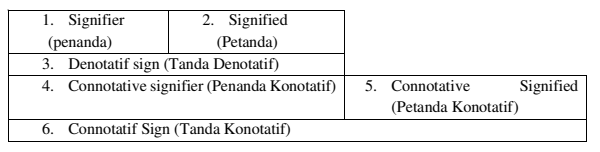

Penjelasan tabel di atas terlihat bahwa tanda denotative (3) terdiri atas penanda (1) adalah aspek citra bunyi semacam kata representasi visual atau coretan, yakni apa yang dilakukan dan 
apa yang ditulis atau dibaca dan penanda (2) adalah gambaran mental atau konsep dimana citra-bunyi itu disandarkan, akan tetapi pada saat bersamaan tanda denotative adalah juga penanda konotatif(4) (Multazam, Skripsi, 2013: 36).

Oleh karena itu, penelitian ini menganalisis tanda citra perempuan dalam teks SNAA menurut Islam dari setiap bagian yang menyertakan tokoh perempuan, dalam hal ini Rohimah, dengan menggunakan analisi semiotika.

\section{HASIL DAN PEMBAHASAN}

1. Citra wanita penyabar

Penyabar menurut KBBI adalah orang yang bersikap tenang (tidak terburu nafsu dan tidak lekas marah). M. Amin Syukur (Jurnal Walisongo, Vol 20, No. 2, 2012: 400) berpendapat sifat Sabar (cabr) dalam Islam menempati posisi yang istimewa sebagai inti perbuatan hati ('amal al$q u l \hat{b} b$ ). Al-Qur' an mengaitkan sifat sabar dengan bermacam-macam sifat mulia, antara lain keyakinan (QS. alSajdah [32]: 24); syukur (QS. Ibrahim [14]: 5); tawakal (QS. alNahl [16]: 41-42); takwa (Ali Imran [3]: 15-17); dan, shalat (QS. alBaqarah [2]: 45-46). Melalui ayatayat tersebut di atas, sabar dapat dimaknai sebagai bentuk pengekangan (al-\%abs wa'l-kuf), dari segala sesuatu yang tidak disukai karena mengharap rida Allah, seperti musibah kematian, sakit, kemiskinan, dan juga hal-hal yang disukai, seperti kenikmatan duniawi yang disukai oleh hawa nafsu. Oleh karena itu, sabar menurut Dzunnun al-Mishry adalah menjauhkan diri dari segala sesuatu yang bertentangan dengan syariat, tenang saat ditimpa musibah, dan menampakkan kecukupan ketika dalam kefakiran.

Penggambaran kesabaran dalam teks SNAA dipaparkan secara implisit oleh pengarangnya. Tokoh Rohimah yang dihina, dibenci dan diusir karena penyakit suaminya. Orang-orang juga mempertanyakan kenapa Rohimah masih mempertahankan dan menghargai Nabi Ayub yang memiliki penyakit busuk, hal tersebut merupakan ujian keimanan Rohimah. Ketika cobaan demi cobaan diterima dan menyudutkan posisi Rohima, datanglah ilham dari Allah yang menggerakkan Rohimah untuk membawa pergi Nabi Ayub ke pengasingan. Cuplikan teks yang berkaitan dengan pembahasan tersebut dapan di lihat pada kutipan berikut:

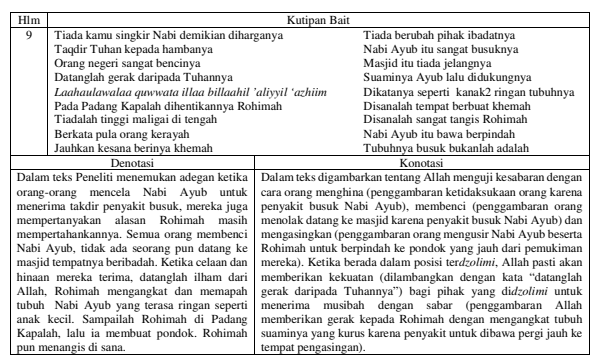


Kutipan tersebut apabila dilihat dari perspektif Islam sudah menggambarkan bentuk sifat sabar yang diterima oleh para tokoh, terutama tokoh perempuannya, dalam hal ini Rohimah. Meskipun hinaan dan pengusiran ditujukan kepada Nabi Ayub, namun Rohimah sebagai istri pun secara tidak langsung mendapatkan dampaknya.

Penggubah SNAA juga memberikan ilustrasi sosok Rohimah yang diberi cobaan oleh iblis yang berbuat fitnah dengan mengatakan kepada banyak orang agar menjauhi Rohimah karena penyakit suaminya yang busuk penuh darah dan nanah pada tangan. Menyikapi hal tersebut, orang-orang pun menolong Rohimah dengan memberi upah makanan yang dihambur-hamburkan (ke tanah), diperlakukan demikian, Rohimah bersabar menerima perlakuan tersebut. Ujian iblis kepada Rohimah dapat dilihat pada kutipan berikut ini:

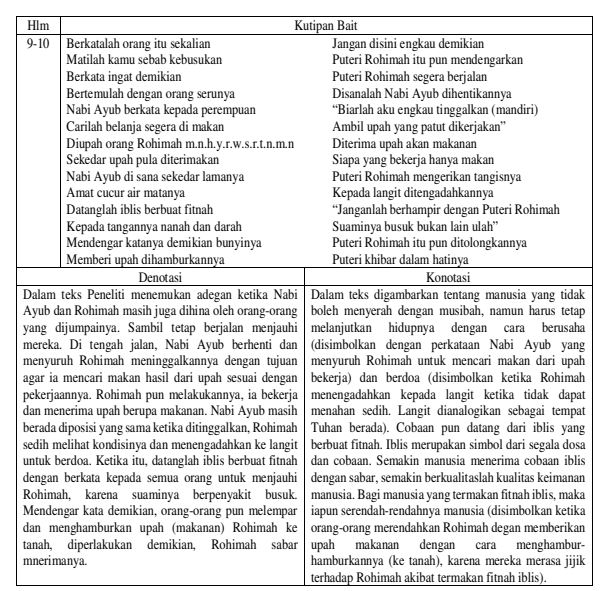

Kutipan di atas merupakan ujian kesabaran dalam bentuk lainnya, yaitu fitnah iblis. Iblis dapat menjelam menjadi apa saja dan siapa saja untuk menggoda keimanan manusia, salah satunya dalam wujud manusia. Apabila manusia mengikuti fitnah dan godaan iblis, maka ia adalah pengikut iblis, bahkan segala tindakan adalah perwujudan yang tidak baik, dalam kasus dalam teks adalah menghamburkan upah makanan karena merasajijik dengan Rohimah. Memberikan sesuatu kepada orang lain dengan cara menghamburkan ke tanah merupakan wujud tindakan yang rendah. Untuk menyikapi hal tersebut hanyalah dengan kesabaran.

2. Citra wanita sopan dan lembut saat bicara

Sopan (KBBI) memiliki arti beradab (tentang tingkah laku, tutur kata, pakaian dan sebagainya). Ketika berkata dan bertindak sopan, maka terdapat kelembutan dalam perkataan dan perbuat tersebut. Sehingga, sopan dan lembut saat bicara merupakan satu kesatuan dalam tindakan yang dijadikan panutan dalam berkomunikasi menurut prespektif Islam.

Menurut Ali Mudlofir (Jurnal Islamica, Vol. 5, No.2., 2011: 369) kedua istilah di atas termasuk dalam enam etika berkomunikasi dalam $\mathrm{Al}$ Qur'an yang disebut dengan qawl 
ma'rufa yaitu perkataan yang baik, sopan, indah, halus, penuh penghargaan, menyenangkan, dan sesuai dengan kaidah hukum dan logika. Dalam pengertian tersebut, tampak bahwa perkataan yang baik adalah yang sesuai dengan status dan latar belakang orang yang diajak bicara.

Penggambaran karakter Rohimah yang sopan dan lembut bicara terdapat dalam teks. Terdapat pada adegan ketika Rohimah kembali pulang dan menemui Nabi Ayub. Rohimah terkejut dengan keberadaan sosok orang muda yang tampan. Sebenarnya sosok itu adalah Nabi Ayub yang telah sembuh dari sakit. Melihat kehadiran Rohimah, Nabi Ayub berhenti shalat dan menyuruh Rohimah untuk mendekat dan menanyakan siapa gerangan yang sedang dicari. Rohimah datang mendekat memenuhi panggilan Nabi Ayub dan menjawab lembut bahwa ia sedang tersesat karena Nabi Ayub meninggalkannya. Uraian tersebut terdapat pada kutipan berikut ini:

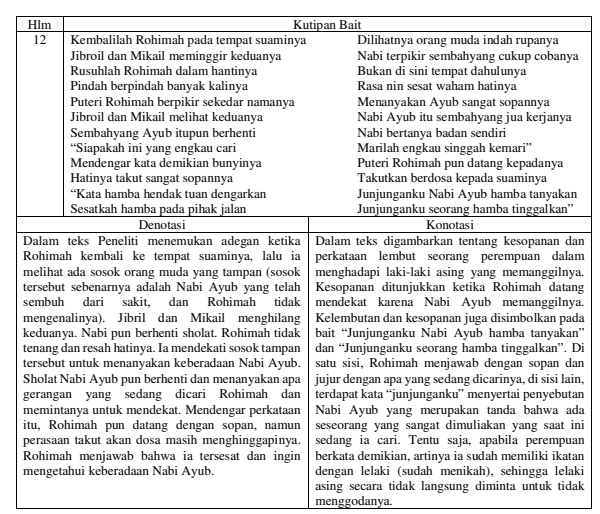

Pemilihan kata 'junjungaku' merupakan kata penghormatan dan sayang kepada sang suami. Meskipun kala itu, Rohimah merasa khawatir dan takut akan keberadaan sosok asing memanggilnya, Ia tetap berkata sopan, lembut dan tidak panik dalam bersikap.

3. Citra wanita berakhlak baik

Akhlak (KBBI) berarti budi pekerti. Akhlak yang baik menggambarkan budi pekerti dan kelakuan yang mulia. Menurut Sabar Budi Raharjo (Jurnal Pedidikan dan Kebudayaan, Vol. 16, No. 3, 2010: 233-234) Akhlak mulia adalah sifat yang terpatri dalam jiwa, yang darinya terlahir perbuatan-perbuatan dengan mudah tanpa memikirkan dan merenung terlebih dahulu. Jika sifat yang tertanam itu darinya terlahir perbuatan baik dan terpuji menurut rasio dan syariat maka sifat tersebut dinamakan akhlak yang baik. Akhlak yang baik atau mulia tentunya akhlak yang tidak bertentangan dengan kaidah agama, adat dan hukum yang diterima oleh masyarakat. Akhlak mulia tersebut dapat berupaa rasa tanggung jawab atas semua yang diucapkan atau dikerjakan. Kemauan untuk menuntut ilmu, menghormati akal mendorong untuk meneliti dan merenung, memilih kebenaran dan kebaikan, saling memberi nasehat, bersabar, dan beramal. Masih banyak akhlak mulia 
yang bisa diterapkan namun pada dasarnya adalah semua perbuatan dan perilaku yang dapat mengangkat harkat dan martabat sebagai manusia yang dimuliakan.

Penggambaran karakter akhlak yang baik ada pada diri sosok Rohimah sejak remaja dan merupakan puteri kesayangan kerajaan dari Negeri Syam. Ia terkenal sebagai seorang puteri yang memiliki kualitas dunia dan akherat, dalam hal ini digambarkan sebagai sosok yang memiliki banyak ilmu dan rajin beribadah. Sepertinya, ilmu agama sudah diperkenalkan oleh orang tua di lingkungan kerajaan, hal ini dapat membentuk akhlak pribadi mulia dalam diri Rohimah ketika besar. Gambaran tersebut terdapat pada kutipan berikut ini:

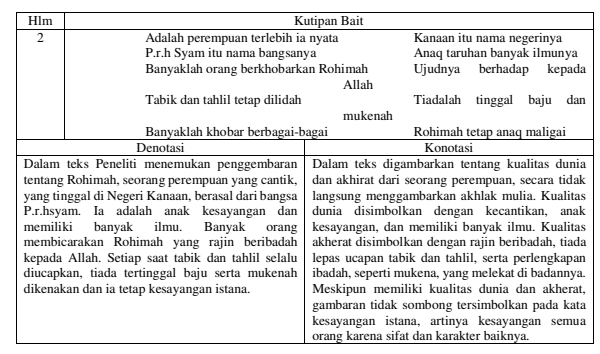

Sifat dermawan juga ditunjukkan Rohimah. Ketika itu, Rohimah sudah menikah dengan Nabi Ayub dan dikarunia sepasang anak kembar yang elok rupawan. Rohimah dan suaminya sangat bahagia mendapatkan anugerah tersebut, mereka pun sangat bersyukur dengan cara memberi jamuan sedekah kepada fakir miskin diiringi dengan. Bait yang menyatakan Rohimah merupakan sosok yang dermawan terpapar pada bait berikut ini:

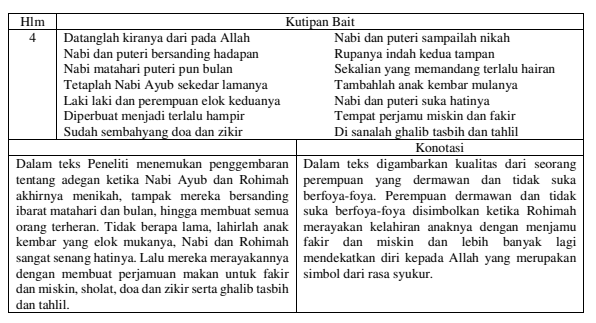

Kutipan di atas menggambarkan bahwa Nabi Ayub dan Rohimah samasama memiliki akhlak yang baik. Akhlak Nabi Ayub yang memang terkenal dermawan dan rajin beribadah diimbangi dan semakin ditularkan karakter tersebut kepada Rohimah. Semua akhlak tersebut merupakan perwujudan kecintaannya kepada Allah swt.

Hormat kepada suami adalah salah satu dari perwujudan akhlak mulia lainnya. Untuk tindakan akhak mulia tergambarkan pada halaman 14, gambaran ketika Nabi Ayub sudah sembuh dari sakitnya, diiringi oleh Rohimah, mereka berjalan bersama, kembali ke negerinya. Ketika berjalan, Rohimah berjalan di belakang suaminya. Hal tersebut dipaparkan pada kutipan berikut ini:

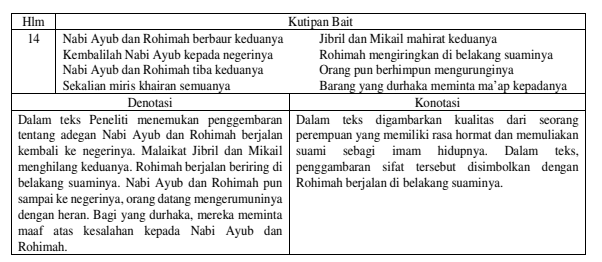




\section{A. SIMPULAN}

Berdasarkan data-data hasil dan pembahasan di atas, maka kesimpulan dan saran sebagai berikut:

\section{A. Kesimpulan}

SNAA merupakan teks cerita ketauladanan Nabi Ayub dan istrinya. Dalam teks terdapat sosok isteri Nabi Ayub bernama Rohimah yang memiliki gambaran perempuan dalam perspektif Islam. Dari ke empat citra yang menjadi ukuran, hanya 3 citra perempuan yang yang mengambarkan Rohimah dalam teks SNAA, antara lain citra penyabar, citra sopan, lembut saat bicara d.an citra berakhlak baik.

\section{DAFTAR PUSTAKA}

Aminuddin. 1991. Pengantar Apresiasi Karya Sastra. Bandung: CV Sinar Baru.

Hasbi, Indra. 2004. Potret Wanita Sholehah. Jakarta: Penamadani.

Ikram Achadiati. 1997. Filologia Nusantara, Jakarta: Pustaka Jaya.

Liaw Yock Fang. 2011. Sejarah Kesusastraan Melayu Klasik. Jakarta: Yayasan Obor Indonesia.

Lubis, Nabila. 2001. Naskah, Teks dan Metode Penelitian Filologi. Jakarta: Yayasan Media Alo Indonesia
Lantini, Susi Endah. 1996. Refleksi Nilai-nilai Budaya Jawa dalam Serat Suryaraja. Jakarta: CV Putra Sejati Raya Jakarta

Multazam. 2013. Citra Perempuan dalam Film Kehormatan di Balik Kerudung (Analisis Semiotik). Skripsi Jurusan Komunikasi dan Penyiaran Islam Fakultas Dakwah dan Komunikasi UIN Sunan Kalijaga: Skripsi Tidak Diterbitkan.

Mulyadi, Sri Wulan Rujiati. 1994. Kodikologi Melayu di Indonesia. Depok: Fakultas Sastra UI.

Nurhasanah. 2016. CitraPerempuan Islam dalam Film Amira dan Sam. Skripsi Jurusan Komunikasi dan Penyiaran Islam Fakultas Dakwah dan Komunikasi UIN Sunan Kalijaga: Skripsi Tidak Diterbitkan.

Pawito. 2007. Penelitian Komunikasi Kualitatif. Yogyakarta: LKiS.

Roza, Ellya. 2011. Naskah Melayu. Pekanbaru: Yayasan Pusaka Riau.

Saputra, Karsono. H.. 2008. Pengantar Filologi Jawa. Jakarta: Wedatama Widya Sastra. 
Saidi, Shaleh. 2003. Melayu Klasik: Khazanah Sastra Sejarah Indonesia Lama. Denpasar: Laras-Sejarah.

Sobur, Alex. 2006. Semiotika Komunikasi. Bandung: Remaja Rosdakarya.

Wieringa, E.P. 2007.Catalogue of Malay and Minangkabau Manuscripts, Vol. Two. Leiden: Leiden University Library.

Yuliatuti, Fitri. 2005. Citra Perempuan dalam Novel Hayuri Karya Maria Etty. Skripsi Jurusan Sastra Indonesia Fakultas Sastra dan Seni Rupa Universitas Sebelas Maret: Skripsi Tidak Diterbitkan.

Website:

Badan Pengembangan dan Pembinaan Bahasa Kemdikbud. Tersedia: http://kbbi.web.id. [diakses 15 Februari 2017].

Bugi, Mochamad. 2008. "Sifat Malu Kaum Wanita". Online. http:// www.dakwatuna.com/2008/02/ 21/405/sifat-malu-kaum-wanita/ \#axzz4YhvSIP6e. Diakses pada 15 Februari 2017

Raharjo, Sabar Budi. 2010. "Pendidikan Karakter Sebagai Upaya Menciptakan Akhlak Mulia”. Jurnal Pendidikan
Kebudayaan. http://jurnal dikbud.kemdikbud.go.id/ index.php/jpnk/article/view/456/ 303. Diakses pada 15 Februari 2017

Rohmawati, Ai. 2013. "Citra Perempuan dalam Naskah Ratu Dewi Maleka: Kajian Feminisme Ideologis" dalam Jurnal Jumantara Vol. 4 No. 4 November. http:// www.perpusnas.go.id/magazine/ citra-perempuan-dalam-naskahratu-dewi-maleka-kajian-feminisideologis/. Diakses pada 15 Februari 2017.

Said, Ummu. 2014. Tanda Akhlak yang Baik. https://muslimah.or.id/ 5407-tanda-akhlak-yangbaik.html. Diakses pada 15 Februari 2017

http://journal.walisongo.ac.id/ index.php/walisongo/article/view/ 205 